
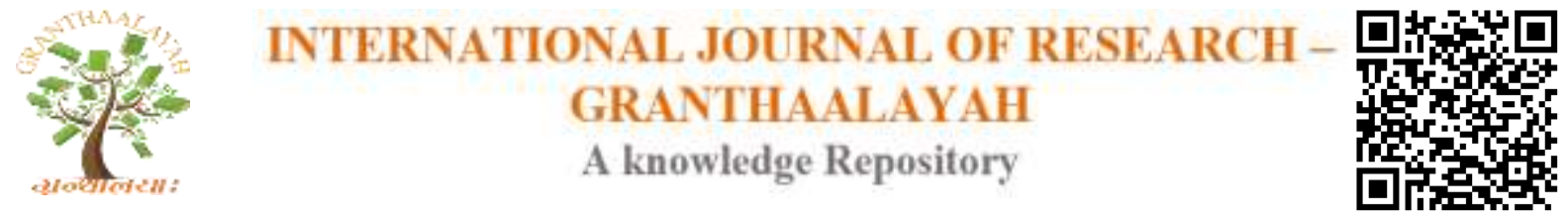

Social

\title{
FISHERWOMEN IN DEVELOPMENT: SOME REFLECTIONS FROM KERALA 'EXPERIENCES'
}

\author{
Sayyid Abdulla Shakir *1 \\ ${ }^{* 1}$ Researcher, School of Social Sciences, Central University of Gujarat, Gandhinagar, India
}

\begin{abstract}
Kerala, southern fringe of India has different story of development from the rest of Indian states. The implementation of different policies by the government has been resulted in the betterment of different marginalized communities, especially in the case of women empowerment. For women empowerment, state government has initiated may programs with the support of other local bodies including government and non-government organizations like Kudumbashree program, Gender park etc. It has created many opportunities for women to come forward to main stream of the society and engaging in many public activities. This paper is an attempt to look at state sponsored program for fisher women empowerment called 'Society for Assistance to Fisherwomen' (SAF), for uplift of fisherwomen, with the support of both secondary material and ground reality. This paper also discusses about development model of Kerala with special focus on women empowerment.
\end{abstract}

Keywords: Kerala Development; Women Empowerment; Society for Assistance to Fisherwomen.

Cite This Article: Sayyid Abdulla Shakir. (2017). "FISHERWOMEN IN DEVELOPMENT: SOME REFLECTIONS FROM KERALA 'EXPERIENCES'." International Journal of Research - Granthaalayah, 5(7), 140-150. 10.29121/granthaalayah.v5.i7.2017.2116.

\section{Introduction}

Kerala, the southern fringe of Indian sub-continent is very different form the rest of Indian states for its social development indicators, which reflected in living standard of the community. Development Model or development experience 'of Kerala (KMD) has been compared with many other developed' and under developed countries, for example, life expectancy of Keralites is 70 and life expectancy of America 72, and birth rate of America and Kerala is 18 and 16 respectively (Panikar 1979: 1804, Veron 2001: 605).

Like many of other Indian states, Kerala was considered as one of the most backward states of the country (Devika 2010:799). Political dominance of both left democratic front (LDF) and united democratic front (UDF) and their regular ruling out from the power resulted in competition among political alliances either to implement or promote programs for developing 
and improving living condition of people (Steur 2009: 221, Öktem 2012:314). In each electoral manifesto, both political alliances tried to highlight and give priority to the community development policies (Sato 2004:292). Apart from this Kerala has socially and politically wellorganized society, stand for their development rights under different political and social organizations which contributes to the state (Nag 1989: 418).

In this paper, I will discuss about the role of development in Upliftment of fisher women who are considered as outlier from development process of the state. For purpose of the analysis, this paper has been divided in to five parts. First part is introduction to current paper. Second part will discuss on how Kerala has been labeled as 'model of development' for the rest of Indian states. Third part will be a glance on women development programs initiated by state government. Fourth part of this paper will be discussed on how fishing community became part of mainstream of the society by the implementation of Society for Assistance to fisherwomen (SAF) at a great level by engaging various income generating activities. Final part of paper will be summary and conclusion with some recommendations.

\section{Methodology}

As mentioned earlier, this article is mainly based on primary resources like personal interviews, newspaper reports, government offices. Personal interviews have been conducted during 2015-16 in coastal area of Punthura village in Thiruvanadapuram District -the capital district of state-. Fishing and fishing related activities are main source of income. 94 respondents have interviewed including group interviews. Along with primary data, secondary resources also used in this article like journal article, book etc.

\section{Why Kerala is a Model for Development}

Kerala has been called as a -political laboratory of India- ${ }^{1}$ where many development activities were experimented from the formation of the state by different political alliances for improvements of living conditions of people with the implementation of welfare schemes by minimum expenditure of low per-capita income and maximum utilizing social capital. By the last quarter of $20^{\text {th }}$ century, Kerala became a model in terms of its development for rest of Indian states and comparable with many developed and developing countries. Development experience of Kerala was a puzzle for policy experts as the improvements in the living standard of Keralites have taken place within low per capita income but without rapid economic growth. It was widely accepted assumption among development experts that development is not possible without economic growth (Parayil 2000:1). Maintaining or improving material quality of people's life in terms of education, health and social security within low per capita are the main features of Kerala development experience. But, when it is compared with many other states of India, Kerala is in very low position either in terms of per capita income or health facilities and pension payment.

${ }^{1}$ This term coined by K.Raman Pillai in his article 'Politics of Kerala' published by The Indian Journal of Political Science' in 1987. 
Compared to other Indian states, Kerala has unique model for rest in terms of its sustainable development attempts. In a broader sense, sustainability has considered not only on the environmental issues but also focused on improving living standards of people with minimum use of both natural and material resources with low per-capita income. Though Kerala has placed very backward income state than many other states of India, quality of Keralites has been compared with life quality of high-income countries like America and many third world countries (Franke and Chasin 2000).

From the vantage point of regional disparities of the state, south and central parts of Kerala has its place in development process from early 19th century onwards than northern part of Kerala under Travancore and Cochin rulers. Arrival of missionaries and foreign traders to Kerala opened door of knowledge to natives of Travancore and Cochin. ${ }^{2}$ They promoted compulsory primary education for all section of society including untouchables which helped to tackle literacy problem of first generation of Kerala and even it created opportunities of government jobs even for lower section of communities as well (Kannan and Vijayamohanan 2004:32). Under Travancore dynasty, in 1901 total number of school was more than three thousand. They promoted not only government school but also allowed grants for private school. So, various christen groups and other social groups established schools in southern part of Kerala during 19th century, even they opened special school for girls (Tharakan 1984). Women ruler from Travancore dynasty named Rani Gouri Parvathi Bai‘ issued a historical proclamation on about rolling back all kinds of fee in government school running under Travancore territory. Besides Ayurveda and indigenous medical system (Naattuvaydyam), Travancore and Cochin administrators introduced European model of health care system during period of 1811, which helped Kerala to improve health care system more transparent and more effective (Kannan and Vijayamohanan 2004:32). The active participation of community in public debate, having political awareness and keeping consciousness about the rights and duties make Kerala as different one and it helped someway Kerala to be model development for rest of Indian states.

Land reform bill of state government was very important footstep in state's development process. When E.M.S Namboodiripad ${ }^{3}$ came to power government has passed land reform bill in legislative assembly within one week (Ramachandran 2000:98 and Moolakkattu 2007:87) and the bill was known as Kerala Agrarian Relations Bill ${ }^{4}$. It has helped many of low caste people to own the lands with the help of state government subsidies on land prices that caused for their socio-economic developments and at greater level and brought them to the main steam of society at large extent (Franke and Chasin 2000:24).

Like elsewhere in India, Kerala also witnessed that socially promoted customs and practices on the basis of social hierarchies worked as great enemies of social development (Ramachandran 2000:100). But Keralites had broken up these social barriers with massive social actions. Social

\footnotetext{
${ }^{2}$ (See, The Hindu newspaper link: http://www.thehindu.com/2001/01/09/stories/05092523.htm accessed on 10/12/2016).

${ }^{3}$ Comrade ElamkulamManakkalSankaranNamboodiripad popularly known as EMS Nabdudiripad (1909-1998) is one of the founder leader of communist party in India and first Chief Minister of the Kerala state. During his bachelor studies, he left Kerala to join in freedom struggle and jailed in Satyagaraha movement and he fought against caste system during his formal education (see official website of communist party of India http://cpim.org/content/e-m-s-namboodiripad accessed on 10/012/2016).

${ }^{4}$ (See Kerala state government official web portal http://kerala.gov.in/index.php?option=com_content\&view=article\&id=3668\&Itemid=2959, accessed on 10/12/2016).
} 
movements in Kerala during the period of 1920's and 1930's played momentous role in elating living standards of peoples. Similar to other part of the country, Social movements in Kerala during early $20^{\text {th }}$ century was mainly against social evils especially related to women rights like ban of widow remarriages, sati and lack of educational opportunities for them (Manmathan 2013). Matrilineal tradition of state played a crucial role in balancing gender gap in state as women headed family was very common in Kerala among Nayar community and even among Ezhava community (Alexander 2000:152, Kannan 2000:57).

In short, in terms of social development indicators, Kerala has progressive improvements in comparison to rest of Indian states and many developed countries. Political freedom and social opportunities of state in terms of educational access and public health facilities helped the state to be a model of development (Sen 2000: 44).

\section{Empowering Women: A Kerala Experiences}

Kerala has a successful history of community empowerments, especially for women by implementing various flagship programs introduced by both government and non-governmental organizations. Kerala has taken historical footstep by introducing the concept of 'Gender Park' under initiatives of department of social justice of the state government to bring together state, academicians and civil society in a platform to address gender related issues. It aims to generate space for women to come forward to mainstream of society by providing both income generating activities and skill oriented training programs like opening small business ventures, She -Taxi is one of the important initiatives of Gender Park. ${ }^{5}$ Even there are many women empowerment programs which has been discussed some of them above among these program 'Kudumbashree' program became more popular and it became a turning point in the history of the state. ${ }^{6}$ Kudumbashree program aimed for eradication of poverty with the participation of women across the state and many women came to mainstream of community (Williams, Devika and Aandahl 2015:1119). This mission has started as a pilot project named as 'Community Development Society' (CDS), which implemented in two districts of Malappuram and Alappuzha, and then government initiated to scale up this program at state level (Devika and Thampi 2007:35). Now the function of the mission have spread in whole districts of the state covered more than 51percentage of households and crossed 41 lakh members and state government providing grants, subsidies and bank loans according to different endeavor of Kudumbashree. $^{7}$ In the year of 2015-2015, government gave 877.63 lakh as subsidy and grant and awarded amount of 1,280-core rupees loan for different Kudumbashree units (Economic Review 2015: 88). The successful history of this mission with its grass root level participation of people from different region of state helped the government to implement various poverty eradication programs like Mahatma Gandhi National Rural Employment Guarantee Act

\footnotetext{
5 (See official website of gender park http://genderpark.gov.in; accessed on 13/12/2016).

${ }^{6}$ Kudumbasheree is poverty alleviation policy of state government through the participation of women under the department of local governance of state government. It is compound of kudumbam+ shree', which means _she is prosperity of the family“. The mission statement of this program is eradication of Poverty within ten year by empowering women. Program launched in 1998 (see official website of Kumbashreee program. The structure of this program is different functional body from neighborhood groups to ministry level. http://www.kudumbashree.org/?q=vision accessed on 09/03/16).

${ }^{7}$ (See official website of Kudumbashreehttp://www.kudumbashree.org/?q=home accessed on 13/12/16).
} 
(Williams, Thampi, et al. 2012:990) and Basic Service to Urban Poor (BSUP), ${ }^{8}$ Rajeev Awasyojana (RAY). ${ }^{9}$ Beside these programs, Kudumbashree worked as medium of government to organize different programs like conducting various state government awareness programs related to health, education and etc. (Economic Review 2015). Recently state government ministry has decided to recruit women employs from Kudumbashree for Kochi metro in various departments like cleanings, parking areas, restaurants etc. In short, Kerala has projected as model for other Indian states interims empowering women with implementation of various projects and policies especially in case of women.

\section{Fisherwomen in Development: Reflection from Kerala 'Experience'}

Someone may ask if there is successful history of Kudumbashree program they why SAF? Even though Kerala has successful impact of women empowerment by initiatives of Kudumbashree program, it has criticized for it exclusionary pattern of project implementations (Shihabudheen 2013:16). People from certain community were not able enjoy benefits these group activities because of their existing social conditions and it also reflected in allocation of financial support from government financial institutions and faced discrimination from the society in the cases of distributions of profits (Williams, et al. 2011:1278). Fishing communities are one of among these groups; they were not able to enjoy fruits of these projects at greater level according to geographical conditions of this community. Living at the fringe of geographical setting with the ownership of small amount of the land and lack of educational attainments and social positions pushed them from developmental activities of the state, they were considered as outlier from development of the state (Kurien 2000:178). Many Projects, which implemented through Kudumbashree programs was not applicable in coastal areas due to lack of community interest to mingle with other communities and lack of skill oriented women form fishing communities. ${ }^{10}$

From last couple of years, Society for Assistance to Fisherwomen (SAF) has a great role in enhancing socio economic condition of fisherwomen of the state. ${ }^{11}$ SAF is registered organization under Travancore Cochin literary and charitable societies Act. This organization came into existence for betterment of fisher women in Kerala after the destruction thousands of fishermen community by the tsunami in 2004 in coastal area of Kerala, many of them lost their lives, houses and means of livelihood. ${ }^{12}$ There are many initiatives running under this program like Vembanad project and Theeramythri program. These enterprises are aimed the Upliftment of this community and eradication of poverty from fishing folks by collective actions like

\footnotetext{
${ }^{8}$ Basic service to urban poor (BSUP) is a central government sponsored program aiming to wipe out the poverty form Indian urban space. Project can be implemented with the support of state government and government will provide housing for poor urban residents (see official website of Kudumbashreehttp://www.kudumbashree.org/?q=bsup accessed on 13/12/16.)

${ }^{9}$ Rajeev Gandhi national AwasYojana (RAY) is fully fledged program by central government India. Mission of this program is poverty alleviation from the urban areas of India aiming from 2013-2022 by the support of the states and union territories. This project involves maintaining living housing conditions and improving basic social structure (see business standard online news paperhttp://www.business-standard.com/article/news-ani/ccea-approves-launch-of-rajiv-awas-yojana-113090301053_1.html accessed on 13/12/16)

${ }^{10}$ Interview with Ambroos, traditional fisherman from Punthura Thiruvanadapuram. Interview date: 15/10/ 2015

${ }^{11}$ Interviewed Maglin Peter, secretary Theeradesha mahila vedi. Interview date: 14/10/2015

12 See the official website of society for assistance to fisherwomen (http://www.safkerala.org/history.html accessed on 14/12/2016).
} 
implementation of various projects to enhance the income generation by improving livelihood and by providing new collective activities, like promoting and developing new micro enterprises, establishments of new common infrastructure facilities like community training centers, common production centers and crafting marketing supports. ${ }^{13}$ More than 89 cores have spent under these projects through various policies like Tsunami Rehabilitation Program (TRP) with the support of Asian Development Bank, Tsunami Emergency Assistance Program (TEAP) and Prime Minister National Relief Fund (PMNRF). More than 89 cores have spent under these projects through various policies like Tsunami Rehabilitation Program (TRP) with the support of Asian Development Bank, Tsunami Emergency Assistance Program (TEAP) and Prime Minister National Relief Fund (PMNRF). Among this, projects of Theeramythri has spread and done very appreciable footsteps for his grass root level programs. ${ }^{14}$ As part of skill Development of fishing community, SAF has started training institution called "fishing school" in Alappuzha district of Kerala and some more school will be inaugurated in different district of Kerala.

\section{SAF Projects and its Implementation}

As discussed earlier, SAF is working under the rules and regulations from the fisheries department of state government. It has great manpower from government level to community level. The project of SAF will implemented through these working patterns (see chart 1.1)

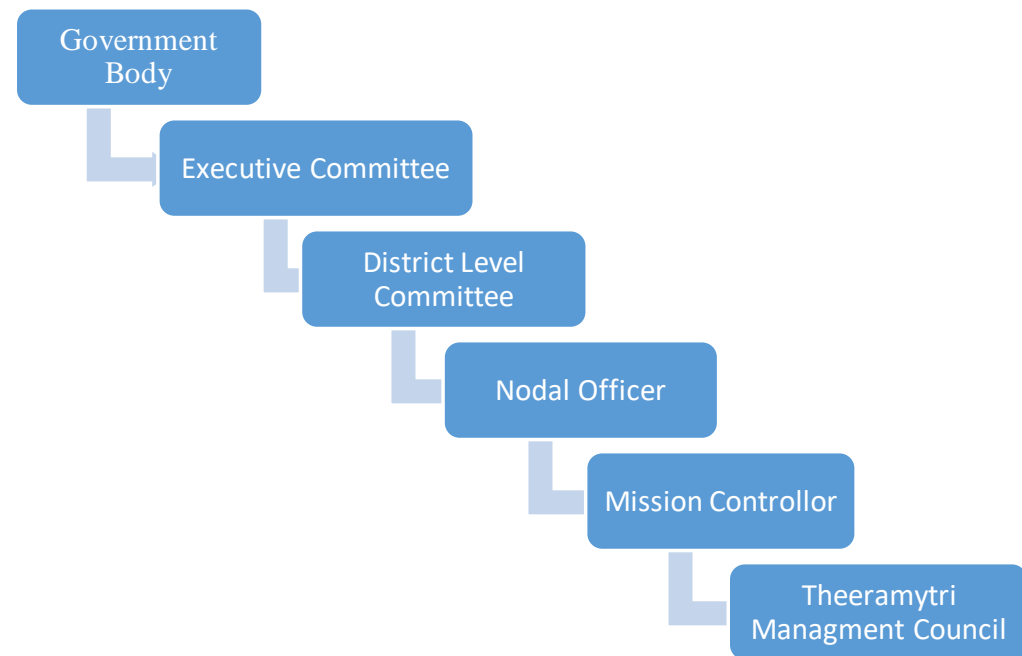

Women Activity Groups

Chart 1.1:

(Source: official website of Theeramythri)

\footnotetext{
13 See The Hindu online newspaper http://www.thehindu.com/todays-paper/tp-national/tp-kerala/Empoweringfishermen/article16159968.ece accessed on 14/12/2016

14 See the official website of society for assistance to fisherwomen (http://www.safkerala.org/history.html accessed on 14/12/2016).

15 See online edition of 'The Hindu ' newspaper http://www.thehindu.com/news/national/kerala/reaching-out-tofisherwomen/article7390792.ece accessed on 13/12/2016.
} 
As discussed earlier, among SAF projects, Theeramythri is one of the important project which aims to encourage alternative livelihood options for fishing community by providing economic assistance to start new micro enterprises. The main objective of this mission is to promote integrated sustainable development by training them to be engaging in other than fishing activities, which help them to secure their economic condition of fishing community. Now this project has been very popular in coastal villages of Kerala, it has a great impact in everyday life of fisher folks than other project like Kudumbashree program. ${ }^{16}$ Now Theeramythri have around 1882 units which are in operation across six different categories viz. garments and textiles, food, coir, fish, supermarket and others along the nine coastal districts of Kerala. (see table .11)

Table No.1.1: District wise number of SAF units

\begin{tabular}{|l|l|}
\hline Name of Districts & Number of SAF units \\
\hline Thiruvananthapuram & 140 \\
\hline Kollam & 422 \\
\hline Alappuzha & 303 \\
\hline Eranamkulam & 276 \\
\hline Thrissur & 207 \\
\hline Malappuram & 124 \\
\hline Kozhikode & 201 \\
\hline Kannur & 125 \\
\hline Kasaragod & 84 \\
\hline Total & $\mathbf{1 8 8 2}$ \\
\hline
\end{tabular}

(Source: Annul Repot ,2016 by central marine fisheries institute, kochi)

\section{Functionalities of SAF}

Like Kudumbashree program, activities of SAF is based on Self-help Groups (SHG). Each group is consisting of 7 to 120 members and average group members are 8 to 11 members. As indicated earlier Each group (women activity group) are organized by under the guidance Theeramythri Management Council (TMC) including local representative of Panchayat or municipal governing body. (Department of Kerala Fisheries). Activities of each groups are coordinated by a leader who are selected by group members. There is no certain criteria or eligibility for selecting group leaders. Generally, they are very active and interested in keeping relation with others. ${ }^{17}$ Annually all groups are re-organized. Formation of groups are based on the interest or based on their skills like garments, production centers and supermarkets etc. accordingly by the collaboration of different public and private agencies government are organizing various training programs for representatives of different SAF members. (Madyamam 2016). This project has brought positive changes in everyday life of fisherwomen especially social and economic period. ${ }^{18}$

\footnotetext{
${ }^{16}$ Interviewed Maglin Peter, secretary Theeradesha mahila vedi. Interview date: 14/10/2015

${ }^{17}$ group Interview with SAF SHG. Interview on 15/10/2015.

${ }_{18}$ Political participation has included in social filed.
} 


\section{Economic and Social Impact}

At large level, economically this project has benefited more than ten thousand costal line families through supporting around two thousand five hundred micro enterprises (Integrated Rural Technology Center). During my filed works, the Respondents were very happy to share positive changes in their everyday life after participating in SAF activities. Economically they are empowered in many ways, (see graph 1.1)

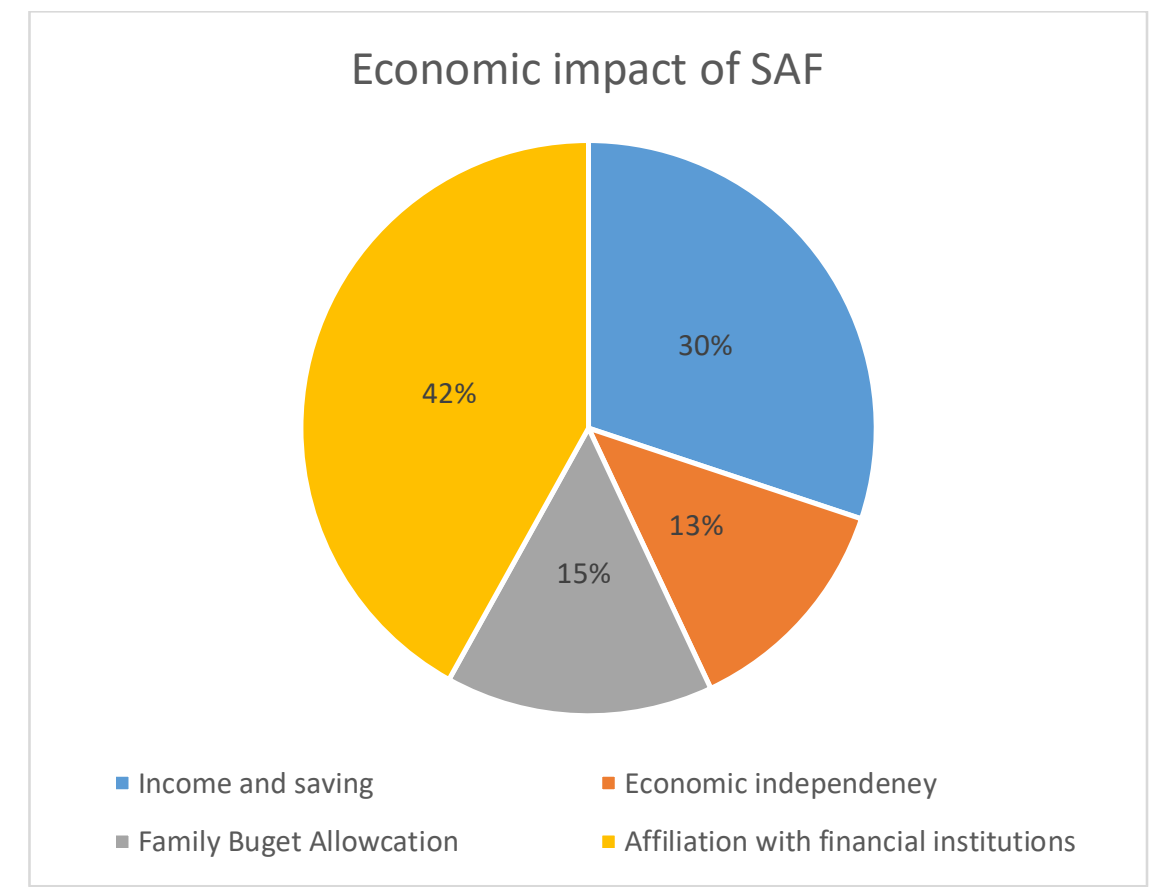

source: filed work

Graph No.1.1:

The graph clearly shows, how SAF has been effected a community in terms of their economic activities. 30 percentage of respondents are stated to save income from their wages, which has been support for them to survive during trawling times, during scarcity of fish and all means of income from the side of male member end for a while SAF members are taking care for house hold expenditures. Earlier during the time of trawling, fishing families depends for daily survive was on public financial systems including public and private bank based on the interest which lost economic stability of fishing community. ${ }^{19}$ Moreover this, they linked to private or national financial systems like banks and co-operative societies.

Along this economic impact in community it has effected social life of fishing community. As a community living at the trip of geographical location and their nature of job somehow they were socially discriminated by other community. Other community were not willing to build social relation and they have felling of insecurity from fishing community. ${ }^{20}$ But, after implementation of there is tragic change in social atmosphere of fishing community. Respondents says, various training and skill development programs helped them to come out form 'community' circle and

\footnotetext{
${ }^{19}$ Interview with Soumya, Leader SHG. Interviewed on 15/10/2015.

${ }^{20}$ Interview with A.J vijayan, Social worker. interviewed on 15/10/2015.
} 
to mingle with other communities. By being engaging in various projects they have to meet different community and strengthen their social relationships (see Graph 1.2)

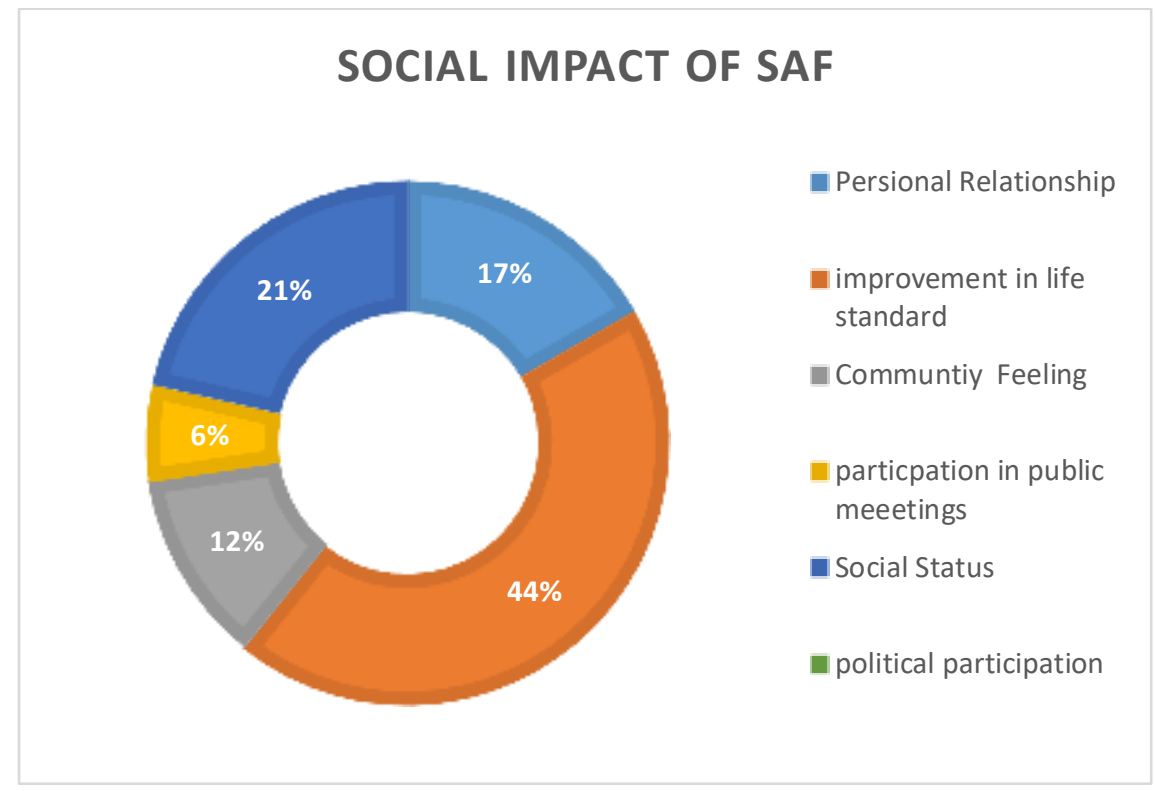

Source filed work)

Graph.1.2:

This graph shows impact of SAF in social life of fisherwomen. 44 percentage of respondents have improved life standard because of increasing economic profile of family members. They are very happy to say that after joining in SAF activities, they are invited in join public meetings and they became part of political alliances. Political participation of fisherwomen helped them to discuss in front of other community and seek solutions. Now, there are many women wings among fishing community, which are affiliated with different political alliances including United Democratic Front (UDF), Left Democratic Front (LDF) and National Democratic Alliance (NDA). Political participation of fisherwomen played a major role preventing exploitations form other community members. ${ }^{21}$ By being part of different projects of SAF, they should attend many training programs in different places. at a great extent, it helped to communicate with other people from different social and political backgrounds. It helped them to build up personal relations and vast their social networks. In short along with economic empowerment of fisherwomen, SAF has acted as medium for social empowerment of fisherwomen.

\section{Conclusion}

This paper was an attempt to look at political, economic and social impact of Society for assistance to fisherwomen project. At a great level, it highly involved in Upliftment of very backward community in the state. Many of development project were lapsed for them because the geographical and occupation nature of community. But, after formation of SAF social and economic profile of fishing community has been increased through implementation of different income generating activities in the coastal areas of state. Engaging women in different professions like food producing sector, supermarkets, fish drying units, helped community to

${ }^{21}$ Interviewed Maglin Peter, interview date. 14/10/2015. 
increase income and leading standard living conditions. Their experiences with other community make them aware about the importance of education motivated them to educate their children.

Many respondents have criticized involvement of local political biasness in recruiting of project officers. They are appointing project officer on the basis political interest without concerning his qualifications. In many cases, political affiliations of officer have caused for discriminations in approval of projects and allocation of subsidies. In Highly market competitions in terms of productions, quality, export and import many stakeholders are questioning the survival of SAF products with the limited number of products and its quality.

Notes: Earlier version of this paper were presented at the school of social sciences, central university of Gujrat

\section{References}

\section{News papers}

[1] "Empowering fishermen." The Hindu. N Ram, 02 Dec. 2016. Web. 21 Feb. 2017.

[2] "Malsyathozhilali stree shakteekaranam: theerapunya parisheelanam thudangi." Madhyamam daily news paper [Eranamkulalm] 6 Nov. 2016, Ernamkulam ed.: n. pag. Web.

[3] Mathew, George. "Amartya Sen \& the Kerala 'model'" The Hlindu. N.p., 9 Jan. 2001. Web. 20 Feb. 2017.

[4] Pillai, R. Ramabhadran . "Reaching out to fisherwomen." The Hindu. N.p., 6 July 2015. Web. 21 Feb. 2017.

[5] The Hindu , newspaper http://www.thehindu.com/news/national/kerala/reaching-out-tofisherwomen/article7390792.ece accessed on 13/12/2016.

[6] The Hindu newspaper link: http://www.thehindu.com/2001/01/09/stories/05092523.htm accessed on $10 / 12 / 2016)$.

[7] The Hindu online newspaper http://www.thehindu.com/todays-paper/tp-national/tpkerala/Empowering-fishermen/article16159968.ece accessed on 14/12/2016

\section{Websites}

[8] Official website of communist party of India http://cpim.org/content/e-m-s-namboodiripad accessed on 10/012/2016

[9] Department of Kerala Fisheries. theeramythir. n.d. $2017 \quad 2 \quad 20$. <http://www. safkerala.org/history.html>.

[10] Integrated Rural Technology Center. IRTC. 2015-2016. $20 \quad 02 \quad 2017$. <http://www.irtc.org.in/index.php/projects/completed-projects>.

[11] Government of kerala . gender park. 5 march 2016. $21 \quad 2 \quad 2017$. <http://genderpark.gov.in/index.html>.

[12] Government of Kerala. kudumbashree. n.d. 212 2017. 〈http://www.kudumbashree.org/pages/7>.

\section{Journal Articles}

[13] Alexander M, William. "Normal Kerala within Abnormal India: Reflections on Gender and Sustainability." The Development Experience: Reflections on Sustainability and Replicability. 1st ed. Vol. 1. Londan: ZED , 2000. 139-56. Print.

[14] Chakraborty, Pinaki. "Intra-Regional Inequality and the Role of Public Policy: Lessons Learnt from Kerala." Economic and Political Weekly, vol. 44, no. 26/27, 2009, pp. 274-281

[15] Devika, J. "Egalitarian Developmentalism, Communist Mobilization, and the Question of Caste in Kerala State, India." The Journal of Asian Studies 69.03 (2010): 799-820. Web. 
[16] Devika, J., and B. V. Thampi. "Between 'Empowerment' and 'Liberation': The Kudumbashree Initiative in Kerala." Indian Journal of Gender Studies 14.1 (2007): 33-60. Web.

[17] Kannan, K.p. "Public Intervention and Poverty Alleviation: A Study of the Declining Incidence of Rural Poverty in Kerala, India." Development and Change 26.4 (1995): 701-28. Web.

[18] Kurien, John. "The Kerala Model: Its Central Tendency and the Outlier." Social Scientist, vol. 23, no. 1/3, 1995, pp. 70-90.,

[19] Manmathan, M. R. "Temple as the Site of Struggle: Social Reform, Religious Symbols and the Politics of Nationalism in Kerala." Advances in Historical Studies 02.02 (2013): 57-69. Web.

[20] Moolakkattu, John S. "Land Reforms and Peaceful Change in Kerala." Peace Review 19.1 (2007): 87-94. Web.

[21] Nag, Moni. "Political Awareness as a Factor in Accessibility of Health Services: A Case Study of Rural Kerala and West Bengal.” Economic and Political Weekly, vol. 24, no. 8, 1989, pp. 417426.

[22] Öktem, Kerem Gabriel. "A Comparative Analysis of the Performance of the Parliamentary Left in the Indian States of Kerala, West Bengal and Tripura." South Asia: Journal of South Asian Studies 35.2 (2012): 306-28. Web.

[23] P. K. Michael Tharakan. "Socio-Economic Factors in Educational Development: Case of Nineteenth Century Travancore." Economic and Political Weekly, vol. 19, no. 46, 1984, pp. 1959-1967.,

[24] Panikar, P. G. K. "Resources Not the Constraint on Health Improvement: A Case Study of Kerala." Economic and Political Weekly, vol. 14, no. 44, 1979, pp. 1803-1809.

[25] Parayil, Govindan. "Is kerala's Development Experience a Model." In Kerala: The Development Experience Reflectios on Sustainability and Replicability. Londan: ZED , 2000. 1261-280. Print.

[26] PILlAi, K. RAMAN. POLITICS OF KERALA. Vol. 48. Delhi: Indian Political Science Association, 1987. 4 vols

[27] Sato, Hiroshi. "Social Security And Well-Being In A Low-Income Economy: An Appraisal Of The Kerala Experience." The Developing Economies 42.2 (2004): 288-304. Web.

[28] Sen, Amartya. Development as freedom. Oxford: Oxford U Press, 2013. Print.

[29] Shihabudheen, N. "What is right and wrong with Kudumbashree: the field Experiences." International Journal of Humanities and Social Science Invention 2.5 (2013): 9-21.

[30] Steur, Luisa. "Adivasi Mobilisation: 'Identity'versus 'Class' after the Kerala Model of Development?." Journal of South Asian Development 4.1 (2009): 25-44.

[31] Véron, René. "The "new" Kerala model: Lessons for sustainable development." World development 29.4 (2001): 601-617.

[32] Williams, Glyn, Binitha V. Thampi, D. Narayana, Sailaja Nandigama, and Dwaipayan Bhattacharyya. "The politics of defining and alleviating poverty: State strategies and their impacts in rural Kerala." Geoforum 43.5 (2012): 991-1001.

[33] Williams, Glyn, J. Devika, and Guro Aandahl. "Making space for women in urban governance? Leadership and claims-making in a Kerala slum." Environment and Planning A 47.5 (2015): 1113-131.

\footnotetext{
*Corresponding author.

E-mail address: Sayyid.shakir@cug.ac.in
} 